\title{
RUMPUT LAUT SEBAGAI BAHAN PENGENTAL PENGGANTI BLENG DALAM PEMBUATAN KERUPUK KARAK YANG AMAN BAGI KESEHATAN
}

\author{
Rohmat Isnaini \\ Guru SMKN 1 Kedawung
}

\begin{abstract}
In processing the manufacture of crackers that develop in the community generally generated from the rest of the rice or rice that is made karup kerupuk by entrepreneurs of karak kerupuk. Rice used as kerupuk karak by the community is usually made of liquid borax (Sodium tetraborate) which is known by the community as a bleng as thickening ingredients. Writing Objective To evaluate the use of seaweed as a substitute of bleng in the manufacture of crackers of karak are at risk to health with a safer natural thickener. This type of research is descriptive quantitative. It is expected that the data from this research is representative to know the concentration of seaweed as a thickening agent in making karup kerupuk by testing dose as control. From the research results can show that seaweed type Eucheuma cottoni can be used as thickening agent, from organoleptic test and hedonic test of the composition of cracker of karak with best taste, texture and color is the composition of seaweed extract $100 \mathrm{ml} / 1 \mathrm{~kg}$ of rice.
\end{abstract}

Keywords: Seaweed, bleng, karup kerupuk

\begin{abstract}
ABSTRAK
Dalam pengolahan pembuatan kerupuk karak yang berkembang di masyarakat pada umumnya dibuat dari sisa nasi atau nasi yang memang dibuat kerupuk karak oleh pengusaha kerupuk karak. Nasi yang dijadikan kerupuk karak oleh masyarakat biasanya berbahan boraks cair (Sodium tetraborate) yang dikenal oleh masyarakat dengan sebutan bleng sebagai bahan pengental. Tujuan Penulisan Mengevaluasi pengunaan rumput laut sebagai bahan pengganti bleng pada pembuatan kerupuk karak yang beresiko terhadap kesehatan dengan bahan pengental alami yang lebih aman. Jenis penelitian ini adalah deskriptif kuantitatif. Diharapkan data dari penelitian ini representatif untuk mengetahui konsentrasi rumput laut sebagai bahan pengental dalam pembuatan kerupuk karak melalui pengujian dosis sebagai kontrol. Dari hasil penelitian dapat menunjukkan bahwa rumput laut jenis Eucheuma cottoni dapat digunakan sebagai bahan pengental, dari uji organoleptik dan uji hedonik komposisi kerupuk karak dengan rasa, tekstur, dan warna yang paling baik adalah komposisi ekstrak rumput laut $100 \mathrm{ml} / 1 \mathrm{~kg}$ nasi.
\end{abstract}

Kata Kunci : Rumput laut, bleng, kerupuk karak

\section{PENDAHULUAN}

Dalam pengolahan pembuatan kerupuk karak yang berkembang di masyarakat pada umumnya dibuat dari sisa nasi atau nasi yang memang dibuat kerupuk karak oleh pengusaha kerupuk karak. Nasi yang dijadikan kerupuk karak oleh masyarakat biasanya berbahan boraks cair (Sodium tetraborate) yang dikenal oleh masyarakat 
dengan sebutan bleng sebagai bahan pengental. Boraks biasa digunakan pada kerupuk yang berbahan dasar tapioka, terigu dan beras. Hal tersebut untuk membantu proses gelatinisasi pati sehingga produk menjadi Kenyal.

Boraks merupakan salah satu zat aditif pada makanan. Yakni zat yang ditambahkan dan dicampurkan pada makanan sewaktu pengolahan makanan dengan maksud untuk mengawetkan makanan serta sebagai pengenyal. Boraks sebenarnya merupakan bahan pembantu dalam industri deterjen, kosmetik, melamin, antibiotik, pestisida, dan metalurgi. Selain itu dalam dunia industri, boraks menjadi bahan solder, bahan pembersih, pengawet kayu, antiseptik kayu, dan pengontrol kecoak. (http://pharmacy-poltekkestanka.blogspot.com).

Melihat kenyataan diatas memperlukan pemecahan yang aman bagi kesehatan. Aman artinya bahan makanan yang dikonsumsi harus bebas dari bahan racun dan berbahaya yang dapat membahayakan kesehatan atau keselamatan manusia (BPOM, 2003).

Rumput laut (Eucheuma cottonii) memiliki kandungan kimia penting lain adalah karbohidrat yang berupa polisakarida seperti agar - agar, Karagenan dan alginat ( Atmadja,1996). Karagenan dan alginat memiliki fungsi salah satunya sebagai pengental.

\section{RUMUSAN PERMASALAHAN}

Oleh karena itu, peneliti menyusun penelitian ini, sebagai salah satu upaya untuk menemukan solusi pengganti bahan bleng sebagai pengental gendar yang dijadikan kerupuk karak dengan bahan pengental alami yaitu menggunakan rumput laut. Rumusan permasalahan penelitian ini adalah apakah rumput laut dapat digunakan sebagai pengental alami untuk menggantikan bleng pada pembuatan kerupuk karak.

\section{HIPOTESIS PENELITIAN}

Hipotesis awal dari penelitian ini adalah Rumput laut dapat digunakan sebagai pengental alami menggantikan bleng pada pembuatan kerupuk karak.

\section{TINJAUAN PUSTAKA}

Rumput laut secara ilmiah dikenal dengan istilah Alga atau Ganggang. Rumput laut termasuk salah satu anggota Alga yang merupakan tumbuhan berklorofil. Dilihat dari ukurannya, Rumput laut terdiri dari jenis mikroskopik dan makroskopik. Jenis makroskopik inilah yang sehari-hari kita kenal sebagai Rumput laut. Namun istilah Rumput laut sebenarnya tidak tepat. Karena secara botani tidak termasuk golongan rumput-rumputan (Graminae) (Poncomulyo, dkk, 2006). 
Alga berdasar pigmen yang dikandungnya dikelompokkan menjadi 4 kelas Winarno (1996) yaitu ganggang biru (cyanophyceae), ganggang hijau (chlorophyceae), ganggang merah (rhodophyceae) atau ganggang coklat (phaeophyceae).

Tabel 1 Karakteristik dari rumput laut pada masing-masing kelas

\begin{tabular}{|c|c|c|c|}
\hline $\begin{array}{l}\text { Jenis Rumput } \\
\text { laut }\end{array}$ & Pigmen & $\begin{array}{l}\text { Zat penyusun } \\
\text { dinding sel }\end{array}$ & Habitat \\
\hline $\begin{array}{l}\text { Hijau } \\
\text { (Chlorophyta) }\end{array}$ & $\begin{array}{l}\text { klorofil } a \text {, klorofil } b \\
\text { dan } \\
\text { karotenoid } \\
\text { (siponaxantin, } \\
\text { siponein, lutein, } \\
\text { violaxantin, } \\
\text { dan zeaxantin) }\end{array}$ & Selulosa & $\begin{array}{l}\text { Air asin; } \\
\text { A ir tawar }\end{array}$ \\
\hline $\begin{array}{l}\text { Merah } \\
\text { (Rhodophyta) }\end{array}$ & $\begin{array}{l}\text { klorofil } a \text {, klorofil } d \\
\text { dan } \\
\text { pikobiliprotein } \\
\text { (pikoeritrin dan } \\
\text { pikosianin). }\end{array}$ & $\begin{array}{l}\text { CaCO3 (kalsium } \\
\text { karbonat),selulosa } \\
\text { dan produk } \\
\text { fotosintetik } \\
\text { berupa karaginan, } \\
\text { agar, fulcellaran } \\
\text { dan porpiran }\end{array}$ & $\begin{array}{l}\text { laut, sedikit } \\
\text { di air tawar }\end{array}$ \\
\hline $\begin{array}{l}\text { Coklat } \\
\text { (Phaeophyta) }\end{array}$ & $\begin{array}{l}\text { klorofil } a \text {, klorofil } c(c 1 \\
\text { dan } c 2 \text { ) } \\
\text { dan karotenoid } \\
\text { (fukoxantin, } \\
\text { violaxantin, zeaxantin) }\end{array}$ & asam alginat & Laut \\
\hline $\begin{array}{l}\text { Pirang } \\
\text { (Chrysophyta) }\end{array}$ & karoten; xantofil & Silikon & $\begin{array}{l}\text { laut; air } \\
\text { tawar }\end{array}$ \\
\hline
\end{tabular}

Sumber: Simpson, 2006

Dalam industri pangan Rumput laut banyak ditambahkan pada berbagai macam produk. Rumput laut yang banyak digunakan adalah dari kelas Rhodophyceae yang mengandung karaginan dan agar-agar. Salah satu spesies yang termasuk dalam kelas Rhodophyceae yang mengandung karagenan yaitu Eucheuma cottony.

\subsection{Eucheuma cottonii.}

Klasifikasi Rumput laut Eucheuma cottonii menurut Indriani dan Sumiarsih (2001) adalah sebagai berikut :

Phylum : Rhodophyceae

Class : Rhodophyta

Sub class : Florideae 
Ordo : : Gigartinales

Fillum : Solieriaceae

Genus : Eucheuma

Spesies : Eucheuma cottonii

Eucheuma cottonii merupakan salah satu jenis rumput laut merah dan berubah nama menjadi Kappaphycus alvarezii karena karagenan yang dihasilkan termasuk fraksi kappa karagenan. Maka jenis ini secara taksonomi disebut Kappaphycus alvarezii. Nama daerah "Cottonii" umumnya lebih dikenal dan biasa dipakai dalam dunia perdagangan Nasional maupun Internasional (Syamsuar, 2007).

Rumput laut Eucheuma cottonii menurut Syamsuar (2007) memiliki ciri-ciri fisik sebagai berikut :

- Mempunyai thallus silindris

- Permukaan licin

- Cartilogeneus

- Keadaan warna tidaklah selalu tetap, kadang-kadang berwarna hijau, hijau kuning, abu-abu atau merah. Perubahan warna sering terjadi hanya karena faktor lingkungan. Kejadian ini merupakan suatu proses adaptasi kromatik, yaitu penyesuaian antara proporsi pigmen dengan berbagai kualitas pencahayaan.

- Penampakan thalli bervariasi mulai dari bentuk sederhana sampai kompleks. Duri-duri pada thallus runcing memanjang, agak jarang-jarang dan tidak bersusun melingkari thallus. Percabangan ke berbagai arah dengan batangbatang utama keluar saling berdekatan ke daerah basal (pangkal).

- Tumbuh melekat ke substrat dengan alat perekat berupa cakram.

- Cabang-cabang pertama dan kedua tumbuh dengan membentuk rumpun yang rimbun dengan ciri khusus mengarah ke arah datangnya sinar matahari.

- Umumnya tumbuh dengan baik di daerah pantai terumbu.

- Habitat khasnya adalah daerah yang memperoleh aliran air laut yang tetap variasi suhu harian yang kecil dan substrat batu karang mati.

Rumput laut Eucheuma cottonii hidup di daerah pasang surut dengan cara menempel di suatu substrat supaya dapat bertahan dan tidak hanyut terbawa arus. Untuk dapat menyerap makanan dari air laut Eucheuma memerlukan gerakan air yang cukup. Jika dasar perairan terdiri dari potongan karang mati dan pasir pergerakan airnya akan cukup. Supaya penyerapan makanan dapat berlangsung terus dan tanaman terhindar dari kerusakan akibat sinar matahari, ketika air laut surut. Lokasinya harus masih digenangi air sedalam $30-60 \mathrm{~cm}$ dan memiliki pH 7,3-8,2. 
Rumput laut Eucheuma cottonii sebagian besar terdiri dari karbohidrat yang sulit dicerna, hingga menimbulkan rasa kenyang yang lebih lama. Disamping itu Rumput laut Eucheuma cottonii juga mengandung protein, lemak dan mineral. sebagaimana telah disajikan pada tabel.

Tabel 2 Komposisi kimia Eucheuma cottonii

\begin{tabular}{|l|c|}
\hline Komposisi & Eucheuma cottonii \\
\hline Kadar air & 16,99 \\
\hline Protein & 2,48 \\
\hline Lemak & 4,30 \\
\hline Karbohidrat & 63,19 \\
\hline Serat kasar & - \\
\hline Abu & 13,04 \\
\hline
\end{tabular}

Sumber : Lestari, dkk (2000)

Selain itu rumput laut juga mengandung enzim, asam nukleat, asam amino, vitamin $(A, B, C, D, E$ dan $K)$ dan makro mineral seperti nitrogen, oksigen, kalsium dan selenium serta mikro mineral seperti zat besi, magnesium dan natrium. Kandungan asam amino, vitamin dan mineral rumput laut mencapai 1020 kali lipat dibandingkan dengan tanaman darat (Hambali, 2004).

Oleh karena itu, penulis tertarik untuk memanfaatkan rumput laut jenis Eucheuma cottonii yang memiliki kemampuan sebagai bahan pengenyal. Kelebihan lainnya dari rumput laut jenis ini memiliki kadar karagenan $54-73 \%$ (Hambali, 2004). Selain itu, penulis memilih jenis Eucheuma cottoni karena mudah diperoleh dipasaran yang biasa digunakan sebagai bahan tambahan es campur.

\subsection{Karaginan}

Karaginan adalah polisakarida linear yang tersusun atas unit-unit galaktosa dan 3,6-anhidrogalaktosa dengan ikatan glikosidik a-1,3 dan a -1,4 secara bergantian. Pada beberapa atom hidroksil, terikat gugus sulfat dengan ikatan ester (Angka dan Suhartono 2000). Struktur karaginan dapat dilihat pada Gambar 1 berikut;

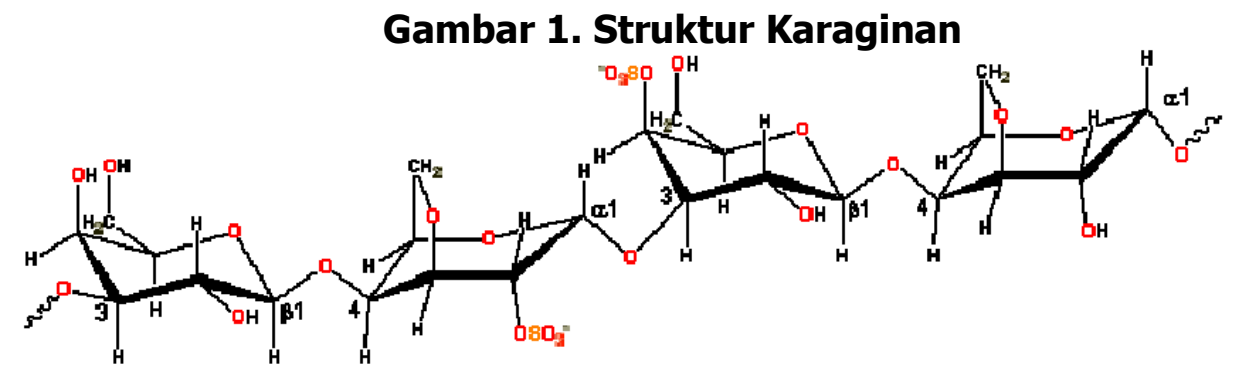


Sumber: Ceamsa (2001)

Unit karaginan mengandung 3 hubungan bolak-balik a-D-galaktopiranosa dan 4 a-D-galaktopiranosa.

Karaginan merupakan getah rumput laut yang diperoleh dari hasil ekstraksi rumput laut merah dengan menggunakan air panas (hot water) atau larutan alkali pada suhu tinggi (Glicksman 1983).

Kappa karaginan tersusun dari (1,3)-D-galaktosa-4-sulfat dan (1,4)-3,6anhidro-D-galaktosa. Karaginan juga mengandung D-galaktosa 6-sulfat ester dan 3,6-anhidro-D-galaktosa-2-sulfat ester. Adanya gugusan 6-sulfat dapat menurunkan daya gelasi dari karaginan, tetapi dengan pemberian alkali mampu menyebabkan terjadinya transeliminasi gugusan 6-sulfat yang menghasilkan 3,6anhidro-D galaktosa. meningkat dan daya gelasinya juga bertambah (Winarno 1996). Struktur kimia kappa karaginan disajikan pada Gambar 2.

\section{Gambar 2 Struktur kimia kappa karaginan}

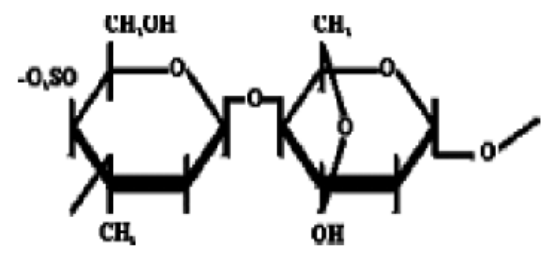

Sumber: Winarno (1996)

Iota karaginan ditandai dengan adanya 4-sulfat ester pada setiap residu D-glukosa dan gugusan 2-sulfat ester pada setiap gugusan 3,6 anhidro-Dgalaktosa. Gugusan 2-sulfat ester tidak dapat dihilangkan oleh proses pemberian alkali seperti kappa karaginan. Iota karaginan sering mengandung beberapa gugusan 6-sulfat ester yang menyebabkan kurangnya keseragaman molekul yang dapat dihilangkan dengan pemberian alkali (Winarno 1996).

Karaginan sangat penting peranannya sebagai stabilizer (penstabil), thickener (bahan pengental), pembentuk gel, pengemulsi dan lain-lain. Sifat ini banyak dimanfaatkan dalam industri makanan, obat-obatan, kosmetik, tekstil, cat, pasta gigi dan industri lainnya (Winarno 1996).

\subsection{Bahan Pengental}

Penambahan bahan aditif pada bahan makanan merupakan suatu substansi bukan gizi yang ditambahkan kedalam bahan pangan dengan sengaja, yang pada umumnya dalam jumlah kecil, untuk memperbaiki penampakan/penampilan, cita rasa, tekstur atau sifatnya. Salah satu bahan aditif yang digunakan dalam makanan adalah zat pengental, pengemulsi atau pemantap. 
Berdasarkan Peraturan Menteri Kesehatan RI No.722/ Menkes/Per/ IX/88 adalah bahan tambahan pangan yang diizinkan pengunaanya sebagai bahan pengental adalah sebagai berikut:

a) Agar, untuk sardin dan sejenisnya (20 g/ $\mathrm{kg}$ ), es krim, es puter dan sejenisnya (10 g/kg), keju (8 g/kg), yogurt (5 g/kg), dan kaldu (secukupnya).

b) Alginat (dalarn bentuk asam, atau garam kalium atau kalsium alginat), untuk sardin dan sejenisnya $(20 \mathrm{~g} / \mathrm{kg})$, keju $(5 \mathrm{~g} / \mathrm{kg})$, dan kaldu $(3 \mathrm{~g} / \mathrm{kg})$.

c) Dekstrin, untuk es krim, es puter dan sejenisnya (30 g/kg), yogurt (10 $\mathrm{g} / \mathrm{kg}$ ), dan kaldu (secukupnya).

d) Gelatin, untuk yogurt (10 g/kg) dan keju $(5 \mathrm{~g} / \mathrm{kg})$.

e) Gom (bermacam-macam gom), untuk es krim, es puter, sardin dan sejenisnya, serta sayuran kaleng yang mengandung mentega, minyak dan lemak (10 g/kg), keju $(8 \mathrm{~g} / \mathrm{kg})$, saus slada $(7,5 \mathrm{~g} / \mathrm{kg})$, yogurt (5 $\mathrm{g} / \mathrm{kg}$ ), minuman ringan dan acar ketimun dalam botol $(500 \mathrm{mg} / \mathrm{kg})$.

f) Karagen, untuk sardin dan sejenisnya (20 g/kg), es krim, es puter dan sejenisnya, serta sayuran kaleng yang mengandung mentega, lemak atau minyak (10 g/kg), yogurt, keju dan kaldu $(5 \mathrm{~g} / \mathrm{kg})$, dan acar ketimun dalam botol (500 $\mathrm{mg} \mathrm{kg}$ ).

g) Lesitin, untuk es krirn, es puter, keju, makanan bayi dan susu bubuk instan $(5 \mathrm{~g} / \mathrm{kg})$, roti, margarin dan minuman hasil olah susu (secukupnya).

h) Karboksimetil selulosa (CMC), untuk sardin dan sejenisnya (20 g/kg), es krim, es puter dan sejenisnya (10 g/kg), keju dan krim $(5 \mathrm{~g} / \mathrm{kg})$, dan kaldu $(4 \mathrm{~g} / \mathrm{kg})$.

i) Pektin, untuk es krim, es puter dan sejenisnya (30 g/kg), sardin dan sejenisnya $(20 \mathrm{~g} / \mathrm{kg})$, yogurt, minuman hasil olah susu, dan sayur kalengan yang mengandung mentega, lemak dan minyak $(10 \mathrm{~g} / \mathrm{kg})$, keju $(8 \mathrm{~g} / \mathrm{kg})$, jem dan marmalad $(5 \mathrm{~g} / \mathrm{kg})$, sirup $(2,5 \mathrm{~g} / \mathrm{kg})$, dan minuman ringan $(500 \mathrm{mg} / \mathrm{kg})$.

j) Pati asetat, untuk es krim, es puter dan sejenisnya (30 g/kg), yogurt dan sayuran kaleng yang mengandung mentega, lemak dan minyak (10 $\mathrm{g} / \mathrm{kg}$ ) dan kaldu (secukupnya).

Boraks maupun bleng tidak aman untuk dikonsumsi sebagai makanan, tetapi ironisnya penggunaan boraks sebagai komponen dalam makanan sudah meluas di Indonesia. Mengkonsumsi makanan yang mengandung boraks memang tidak serta berakibat buruk terhadap kesehatan tetapi boraks akan 
menumpuk sedikit demi sedikit karena diserap dalam tubuh konsumen secara kumulatif. Seringnya mengonsumsi makanan berboraks akan menyebabkan gangguan otak, hati, lemak, dan ginjal. Dalam jumlah banyak, boraks menyebabkan demam, anuria (tidak terbentuknya urin), koma, merangsang sistem saraf pusat, menimbulkan depresi, apatis, sianosis, tekanan darah turun, kerusakan ginjal, pingsan, hingga kematian.

\subsection{Kerupuk karak}

Karak atau kerupuk nasi adalah kerupuk yang sudah banyak dikenal di daerah Jawa tengah, Jawa timur dan masyarakat kota pada umumnya. Di daerah Jawa Timur kerupuk ini biasa dikenal dengan sebutan kerupuk Puli, sedangkan di Jawa Tengah dengan sebutan kerupuk karak. Karak dibuat dari nasi dengan penambahan bleng atau cethithet secukupnya.

Berikut langkah-langkah pembuatan kerupuk karak:

a) Beras yang telah dibersihkan dikukus dalam dandang setengah masak

b) Panaskan larutan bleng sampai mendidih, setelah mendidih masukkan beras setenagh masak tadi kemudian direbus dengan air tersebut secukupnya sampai beras agak masak

c) Kemudian kukus kembali sampai beras tersebut menjadi nasi.

d) Setelah masak kemudian turunkan nasi yang masih panas tersebut kemudian dijojok atau ditumbuk dengan alat penumbuk sampai halus tetapi masih kelihatan nasinya

e) Cetak dalam cetakan kayu yang berbentuk segi empat dan ratakan bagian atasnya

f) Biarkan hasil cetakan tersebut beberapa saat sampai adonan menjadi dingin dan mengeras tetapi masih dapat diiris dengan leluasa

g) Setelah mengeras kemudian diiris (Gambar 3)

\section{METODE PENELITIAN}

\subsection{Jenis Penelitian}

Jenis penelitian ini adalah deskriptif kuantitatif. Diharapkan data dari penelitian ini representatif untuk mengetahui konsentrasi rumput laut sebagai bahan pengental dalam pembuatan kerupuk karak melalui pengujian dosis sebagai kontro.

\subsection{Fokus Penelitian dan Lokus}

Fokus penelitian adalah penggunaan rumput laut sebagai bahan pengental penganti bleng dalam pembuatan kerupuk karak. Penelitian akan dilaksanakan di desa Bendungan, kecamatan Kedawung, dan desa Pelemgadung, kecamatan Puro kabupaten Sragen. 
Gambar 3 Skema pembuatan kerupuk karak secara umum menurut Pusat Penelitian dan Pengembangan Teknologi Pangan

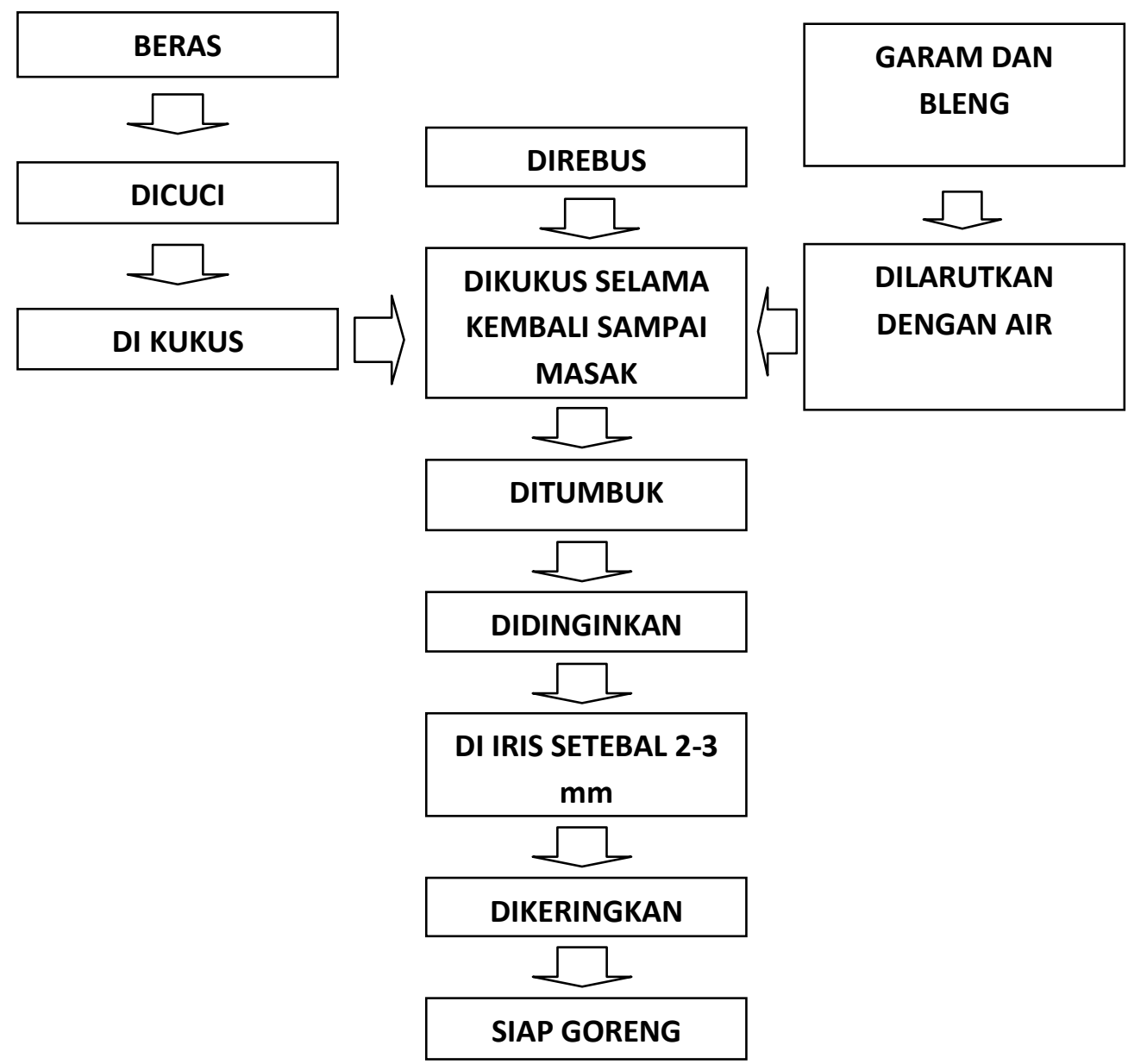

Sumber : IPB, 1982

\subsection{Lingkup/ Populasi dan Responden}

Populasi pada penelitian ini adalah Desa Bendungan, kecamatan Kedawung, kabupaten Sragen. Responden dari penelitian adalah pengusaha kerupuk dan konsumen.

\subsection{Teknik Pengumpulan Data}

Teknik Pengumpulkan data pada penelitian ini:

a. Studi pustaka, yaitu melakukan kajian menggunakan literatur yang berkaitan dengan penelitian ini. Peneliti melakukan studi kepustakaan, baik sebelum maupun selama melakukan penelitian. Studi kepustakaan memuat uraian sitematis tentang kajian literatur dan hasil penelitian sebelumnya yang ada hubungannya dengan penelitian yang dilakukan.

b. Eksperimen, penelitian dengan melakukan percobaan terhadap kelompok eksperimen, kepada tiap kelompok eksperimen dikenakan perlakuanperlakuan tertentu dengan kondisi - kondisi yang dapat di kontrol.

c. Observasi, adalah pengamatan dan pencatatan secara sistematik terhadap gejala yang tampak pada objek penelitian 
d. Dokumentasi, catatan yang dijadikan sumber data dan dimanfaatkan untuk menguji serta untuk menyimpan informasi selama dilakukan penelitian.

\section{HASIL PENELITIAN DAN PEMBAHASAN}

Penelitian pendahuluan uji oranoleptik terhadap sampel kerupuk karak, masing-masing: (1) tanpa bahan pengental, (2) penambahan rumput laut sebagai bahan pengental, (3) kerupuk karak dengan mengunakan bleng. Uji organoleptik atau uji indera atau uji sensori merupakan cara pengujian dengan menggunakan indera manusia sebagai alat utama untuk pengukuran daya penerimaan terhadap suatu produk bahan makanan. Pada uji ini dilakukan dengan tiga kali ulangan tiap sampel.

a. Uji organoleptik Kerupuk Karak

Tabel 3 Hasil uji organoleptik penelitian pendahuluan

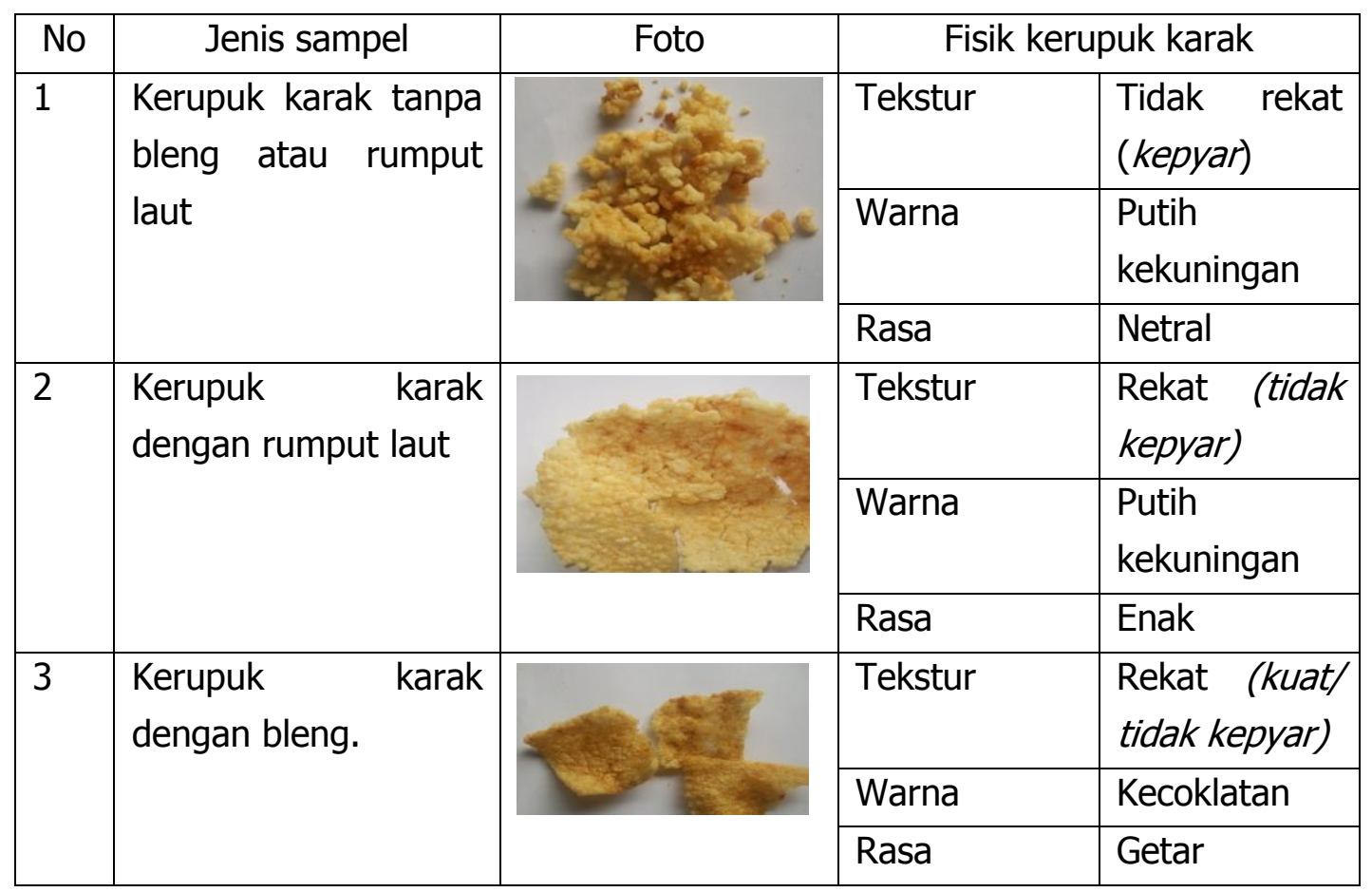

Uji fisik kerupuk karak dari tiga sampel dilakukan secara bersama. Berdasarkan penelitian yang kami lakukan sebanyak tiga kali ulangan tentang fisik kerupuk karak setelah kami membandingkan tiga sampel: (1) kerupuk karak tanpa rumput laut dan tanpa bleng, (2) kerupuk karak dengan rumput laut, (3) kerupuk karak dengan bleng. Diperoleh data penelitian bahwa tekstur yang paling kuat (daya rekatnya) adalah kerupuk karak yang menggunakan bleng, rasa kerupuk karak yang paling enak adalah kerupuk karak yang menggunakan rumput laut, dan warna yang paling baik adalah kerupuk karak dengan rumput laut. 
Perlu kita ketahui bersama bahwa sampel kerupuk karak (3) daya rekat dalam pembentukan tekstur paling kuat, tetapi pada sampel kerupuk karak (3) ini digunakan pengental sintetis yaitu bleng, penggunaan bleng beresiko buruk bagi konsumen. Akibat penggunaan bleng dapat merusak hati, ginjal, limpa, pankreas, otak dan menimbulkan kanker. Begitu banyaknya resiko buruk dari bleng bagi kesehatan, maka dari itu perlu adanya penggantian pengental sintetik dengan pengental alami, sahingga aman untuk kesehatan.

Kerupuk karak yang tanpa menggunakan bleng atau rumput laut teksturnya tidak rekat (kepyar) dan rasanya netral karena tidak diberikan zat tambahan.

Kerupuk karak dengan menggunakan rumput laut, membentuk tekstur kerupuk karak dapat rekat (tidak kepyar) walaupun tidak sekuat bleng, tetapi kerupuk karak dengan menggunakan rumput laut memiliki kelebihan dari warna lebih menarik dan rasanya lebih enak dan tidak menimbulkan rasa getar walaupun banyak mengkonsumsinya.

b. Uji hedonik

Penilaian uji hedonik oleh responden terhadap kerupuk karak terhadap tiga sampel kerupuk karak, (1) kerupuk karak tanpa menggunakan bleng atau rumput laut, (2) kerupuk karak dengan rumput laut, (3) kerupuk karak dengan menggunakan bleng (3). Uji hedonik menggunakan 5 skala penilaian: (1) sangat tidak suka, (2) tidak suka, (3) netral, (4) suka, (5) sangat suka. Pengujian dilakukan di tiga tempat (1) di desa Pelemgadung, kecamatan Karangmalang, kab. Sragen, (2) di desa Puro, kecamatan Karangmalang, kab. Sragen, dan (3) desa Bendungan, kecamatan Kedawung, Kab. Sragen yang melibatkan konsumen dan pengusaha kerupuk karak di masing-masing desa.

\section{Gambar 4 Rata-rata uji hedonik uji pendahuluan}

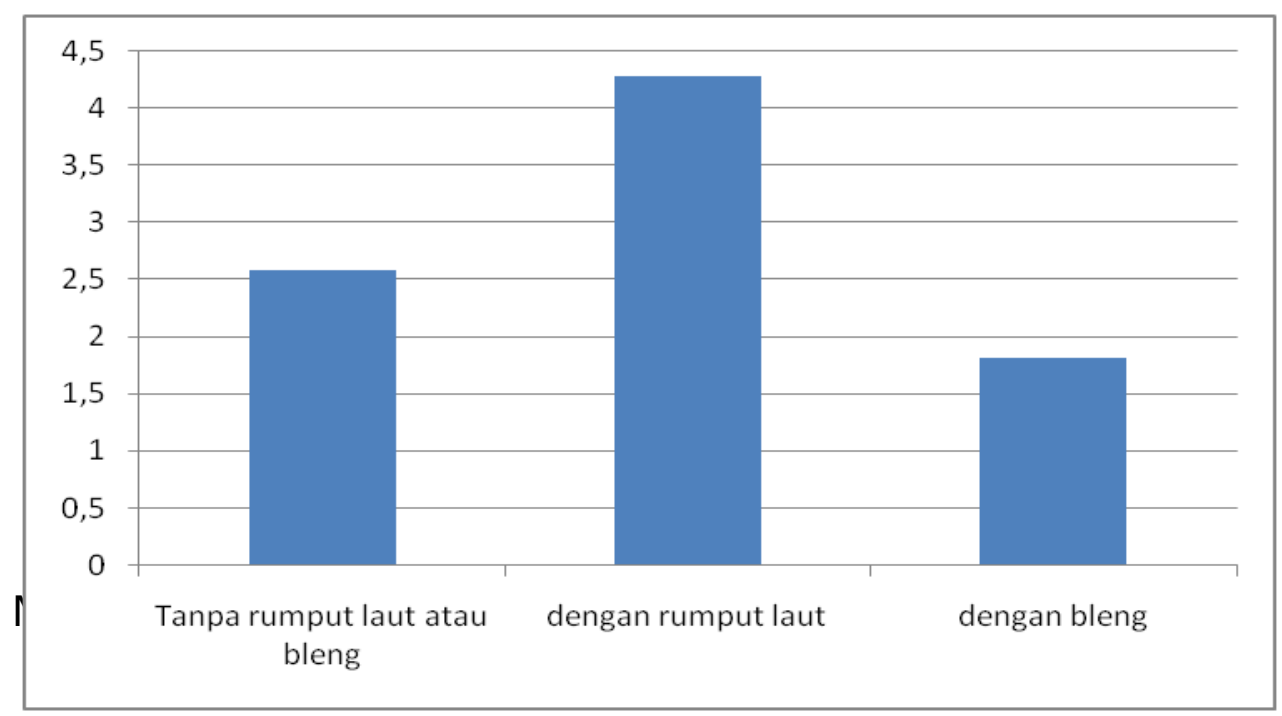


Berdasarkan hasil analisis, dihasilkan nilai antara 1,8056 sampai dengan 4, 27733. Nilai tertinggi 4, 2773 adalah kerupuk karak dengan rumput laut dan nilai terendah adalah 1, 8056 adalah kerupuk karak dengan bleng.

Dari uji organoleptik dan uji hedonik diperoleh kesimpulan bahwa rumput laut dapat digunakan sebagai bahan pengental dan paling diminati responden. Untuk mendapatkan tekstur yang lebih baik maka akan dilakukan penelitian utama sebagai uji dosis.

Berdasarkan hasil uji organoleptik dan uji Hedonik terhadap kerupuk karak dengan perlakuan tanpa penambahan rumput laut atau bleng, dengan penambahan rumput laut, dan dengan penambahan bleng, dipilih satu perlakuan kerupuk karak untuk digunakan pada penelitian utama. Perlakuan kerupuk karak terpilih dari penelitian pendahuluan adalah kerupuk karak dengan penambahan rumput laut.

c. Uji Dosis

Pada penelitian pada tahap ini, dilakukan dengan pembuatan kerupuk karak sampel dengan tiga perlakuan, masing-masing dalam $1 \mathrm{~kg}$ nasi ditambahkan: $50 \mathrm{ml}$ ekstrak rumput laut, $75 \mathrm{ml}$ ekstrak rumput laut, $100 \mathrm{ml}$ ekstrak rumput laut, $125 \mathrm{ml}$ ekstrak rumput laut. Dalam pembuatan dari masingmasing sampel dilakukan sebanyak tiga kali ulangan. Dari hasil penelitian kemudian dilakukan uji organoleptik dan uji hedonik terhadap sampel. Untuk uji hedonik dan uji organoleptik dilakukan di tiga tempat, (1) di desa Pelemgadung, kecamatan Karangmalang, kab. Sragen, (2) di desa Puro, kecamatan Karangmalang, kab. Sragen, dan (3) desa Bendungan, kecamatan Kedawung, Kab. Sragen. 
Tabel 4 Sampel dari masing-masing konsentrasi:

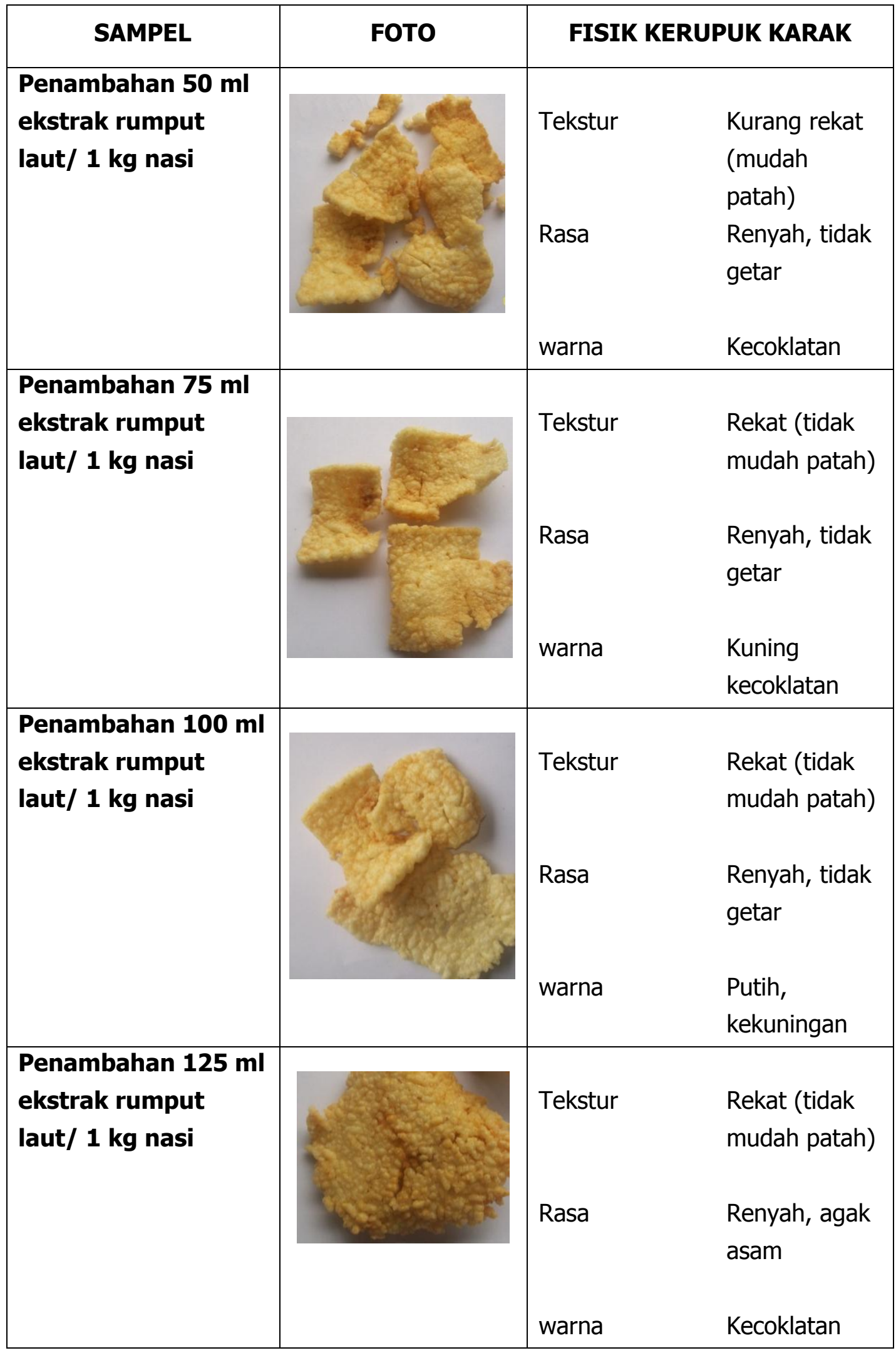

d. Uji Organoleptik

Pengujian organoleptik dengan masing-masing sampel (1) penambahan $50 \mathrm{ml}$ ekstrak rumput laut kedalam $1 \mathrm{~kg}$ nasi, (2 penambahan $75 \mathrm{ml}$ ekstrak rumput laut kedalam $1 \mathrm{~kg}$ nasi, (3) penambahan $100 \mathrm{ml}$ ekstrak rumput laut 
kedalam $1 \mathrm{~kg}$ nasi meliputi rasa, tekstur, dan warna oleh 12 responden dari 3 desa yang melibatkan konsumen dan pengusaha kerupuk. Pengujian organoleptik dilakukan tiga kali ulangan.

Kriteria untuk rasa: (1) tidak enak, getar, (2) tidak enak, tidak getar, (3) enak, getar, (4) enak, tidak getar, (5) sangat enak, tidak getar;

Tekstur: (1) tidak rekat, tidak renyah, (2) tidak rekat, renyah, (3) rekat, tidak renyah, (4) rekat, renyah, dan (5) sangat rekat, renyah;

Warna: (1) Coklat gosong, (2) Coklat, (3) Kuning kecoklatan , (4) Putih kekuning-kuningan, (5) Putih bersih.

Dari percobaan yang dilakukan diperoleh rata-rata sampel (1) penambahan $50 \mathrm{ml}$ ekstrak rumput laut kedalam $1 \mathrm{~kg}$ nasi sebagai berikut: rasa 4,0, tekstur 3,39, dan warna 3,58; sampel (2) penambahan $75 \mathrm{ml}$ ekstrak rumput laut kedalam $1 \mathrm{~kg}$ nasi sebagai berikut: rasa 4,06, tekstur 3,92, warna 4,167; (3) penambahan $100 \mathrm{ml}$ ekstrak rumput laut kedalam $1 \mathrm{~kg}$ nasi sebagai berikut: rasa 4,250, tekstur 4,28, dan warna 4,42; (4) ) penambahan $125 \mathrm{ml}$ ekstrak rumput laut kedalam $1 \mathrm{~kg}$ nasi sebagai berikut: rasa 4,03, tekstur 4,44, dan warna 3,50.

\section{Gambar 5. Rata-rata uji organoleptik masing-masing sampel:}

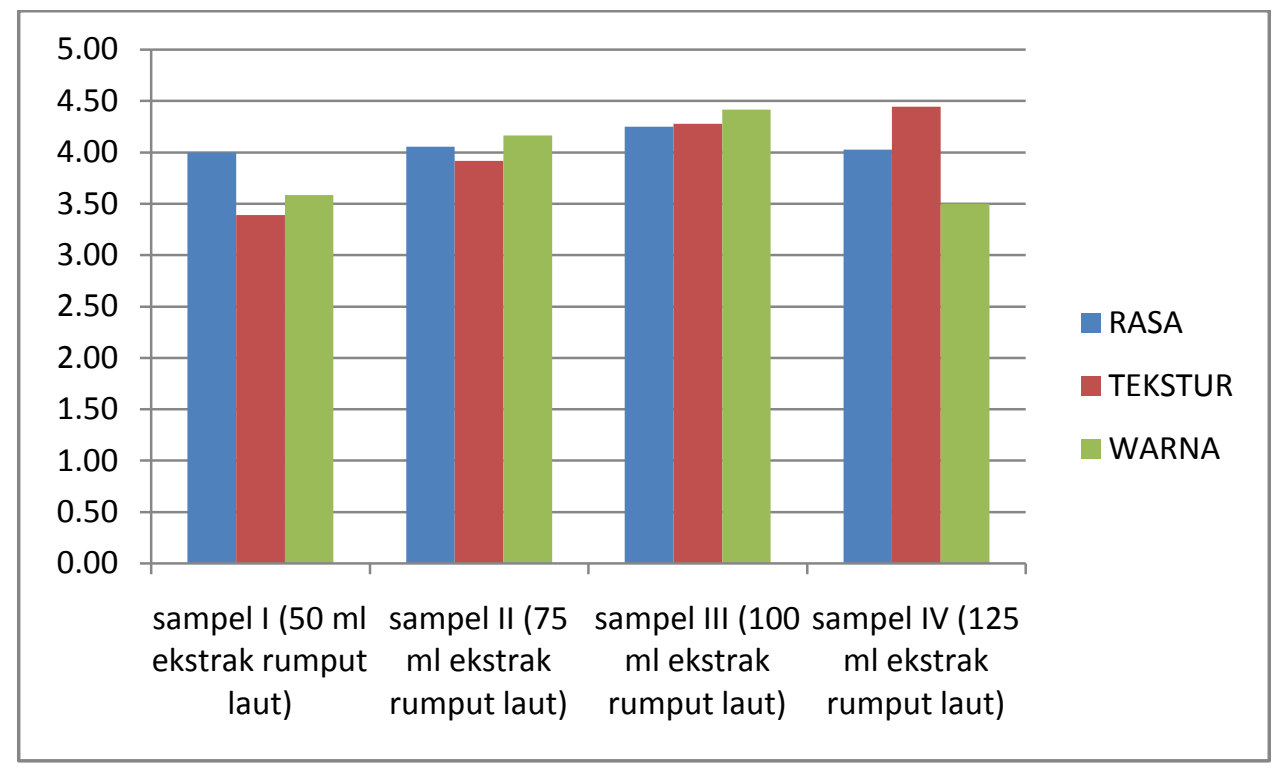

e. Uji Hedonik

Penilaian uji hedonik oleh responden terhadap kerupuk karak terhadap tiga sampel kerupuk karak, (1) penambahan $50 \mathrm{ml}$ ekstrak rumput laut kedalam $1 \mathrm{~kg}$ nasi, (2 penambahan $75 \mathrm{ml}$ ekstrak rumput laut kedalam $1 \mathrm{~kg}$ nasi, (3) penambahan $100 \mathrm{ml}$ ekstrak rumput laut kedalam $1 \mathrm{~kg}$ nasi, (4) penambahan $125 \mathrm{ml}$ ekstrak rumput laut kedalam $1 \mathrm{~kg}$ nasi. Uji hedonik menggunakan 5 
skala penilaian: (1) sangat tidak suka, (2) tidak suka, (3) netral, (4) suka, (5) sangat suka. Pengujian sampel dilakukan tiga kali ulangan.

Dari percobaan yang dilakukan diperoleh rata-rata uji hedonik dari masing-masing sampel: (1) penambahan $50 \mathrm{ml}$ ekstrak rumput laut kedalam 1 $\mathrm{kg}$ nasi adalah 3,75; (2) penambahan $75 \mathrm{ml}$ ekstrak rumput laut kedalam $1 \mathrm{~kg}$ nasi adalah 4,22; (3) penambahan $100 \mathrm{ml}$ ekstrak rumput laut kedalam $1 \mathrm{~kg}$ nasi adalah 4,50; (4) penambahan $125 \mathrm{ml}$ ekstrak rumput laut kedalam $1 \mathrm{~kg}$ nasi adalah 3,78 .

Gambar 6. Rata-rata uji hedonik masing-masing sampel:

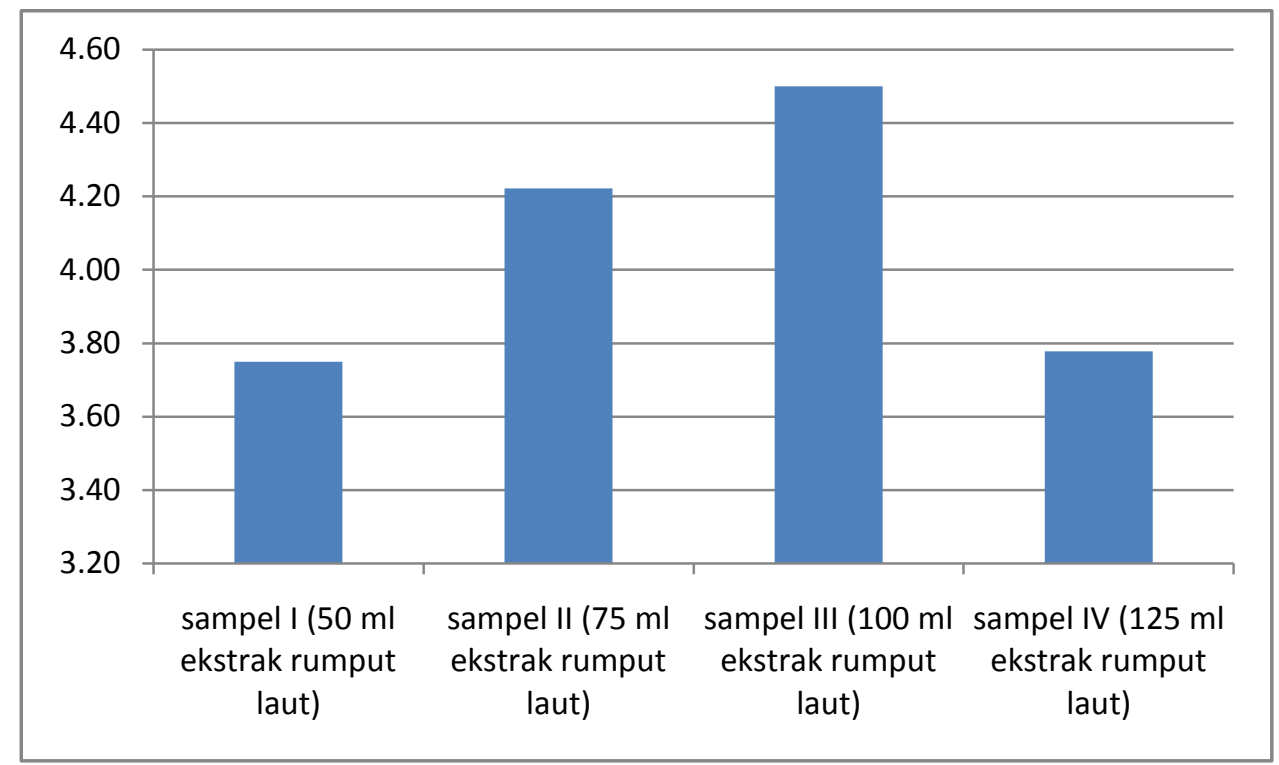

Dari hasil pengujian organoleptik tanggapan responden bahwa dari ketiga sampel: (1) penambahan $50 \mathrm{ml}$ ekstrak rumput laut kedalam $1 \mathrm{~kg}$ nasi, (2) penambahan $75 \mathrm{ml}$ ekstrak rumput laut kedalam $1 \mathrm{~kg}$ nasi, (3) penambahan $100 \mathrm{ml}$ ekstrak rumput laut kedalam $1 \mathrm{~kg}$ nasi. Rasa kerupuk karak yang mendapat respon paling baik adalah sampel (3) dengan rata-rata 4,250. Rasa yang kurang diminati adalah sampel (1) dengan rata-rata 4,00. Tekstur kerupuk karak yang paling baik menurut responden adalah sampel (4) dengan rata-rata 4,44. Tekstur yang kurang diminati adalah sampel (1) dengan rata-rata 3,39. Warna kerupuk karak yang mendapat respon paling baik adalah sampel (3) dengan rata-rata 4,42. Warna yang kurang diminati adalah sampel (4) dengan rata-rata 3,50.

Dari uraian diatas dapat disimpulkan bahwa sampel dengan $100 \mathrm{ml}$ ekstrak rumput laut pada $1 \mathrm{~kg}$ nasi adalah yang paling baik dari uji sensori dari rasa, tekstur, dan warna. Hal ini juga didukung dengan uji hedonik terhadap sampel yang menunjukkan kerupuk karak yang paling diminati adalah kerupuk karak yang terbuat dari 100ml ekstrak rumput laut dengan 1 kg nasi dengan nilai rata-rata 4,5. 


\section{f. Analisa Usaha}

Berdasarkan hasil uji organoleptik dan uji Hedonik terhadap kerupuk karak dengan perlakuan penambahan ekstrak rumput laut $50 \mathrm{ml}, 75 \mathrm{ml}, 100 \mathrm{ml}$ dipilih satu perlakuan kerupuk karak untuk digunakan pada analisa usaha. Perlakuan kerupuk karak terpilih dari penelitian ini adalah kerupuk karak dengan ekstark rumput laut $100 \mathrm{ml} / 1 \mathrm{~kg}$ nasi. Analisa usaha ini untuk mengetahui apakah kerupuk karak dengan rumput laut pada konsentrasi $100 \mathrm{ml}$ ekstrak rumput laut pada $1 \mathrm{~kg}$ nasi layak dikembangankan.

Berikut adalah analisa usaha:

Tabel 5 Analisis R/C

\begin{tabular}{|c|c|c|c|c|}
\hline No & Uraian & Jumlah & $\begin{array}{c}\text { Harga Satuan } \\
\text { (Rp) }\end{array}$ & $\begin{array}{c}\text { Harga } \\
\text { Total (Rp) }\end{array}$ \\
\hline \multirow[t]{2}{*}{1.} & FIXED $\quad$ COST & \multicolumn{3}{|l|}{$(\mathrm{FC})$} \\
\hline & Semua alat & 1 Paket & 1.000 & 1.000 \\
\hline \multirow[t]{6}{*}{2.} & \multicolumn{4}{|l|}{ VARIABLE COST (VC) } \\
\hline & - Beras & $1.000 \mathrm{gr}$ & $8.500 / \mathrm{kg}$ & 8.500 \\
\hline & - Rumput laut & $50 \mathrm{gr}$ & $30.000 / \mathrm{kg}$ & 1.500 \\
\hline & - Bawang & $30 \mathrm{gr}$ & $16.000 / \mathrm{kg}$ & 500 \\
\hline & - Garam & $20 \mathrm{gr}$ & $2.500 / \mathrm{kg}$ & 50 \\
\hline & - Minyak goreng & $250 \mathrm{gr}$ & $12.000 / \mathrm{kg}$ & 4.000 \\
\hline \multicolumn{4}{|c|}{ Total Variable Cost } & 14. 550 \\
\hline \multicolumn{4}{|c|}{ Total Fixed Cost + Variable Cost } & 15. 550 \\
\hline
\end{tabular}

Berdasarkan Perhitungan:

Perkiraan jumlah produk

$=150 \mathrm{biji}$

Fixed Cost (FC)

$=$ Rp. $1 \cdot 000,00$

Variable Cost (VC)

$=$ Rp. $14.450,00$

Fixed Cost + Variable Cost/unit

$=$ Rp. 15. 550,00

Harga produk per biji

$=$ Rp. 150,00

Perkiraan pendapatan

$=$ Rp. $150,00 \times 150$

$=$ Rp. $22 \cdot 500,00$

Target keuntungan

$=$ Rp. $22 \cdot 500,00-R p \cdot 15 \cdot 550,00$

R/C Ratio

$=$ Rp. $6 \cdot 950,00$

$=\operatorname{Rp} 22.500,00 / \operatorname{Rp~15.550,00~}$

$=1,435$ 
Dari analisia diatas maka $\mathrm{R} / \mathrm{C}$ menunjukkan angka $=1,45$ artinya setiap Rp1,00 mengahsilkan Rp 0,45;00. Ini dapat diambil sebuah kesimpulan bahwa kerupuk karak dengan rumput laut layak untuk dikembangkan.

g. Uji Gizi

Berdasarkan hasil uji organoleptik dan uji Hedonik terhadap kerupuk karak dengan perlakuan penambahan ekstrak rumput laut $50 \mathrm{ml}, 75 \mathrm{ml}, 100 \mathrm{ml}$ dipilih satu perlakuan kerupuk karak untuk digunakan untuk uji gizi. Dari analisa usaha karak dengan ekstark rumput laut $100 \mathrm{ml} / 1 \mathrm{~kg}$ nasi disimpulkan bahwa layak dikembangkan berdasar analisis $\mathrm{R} / \mathrm{C}$ sebesar 1,45 . Untuk selanjutnya sampel kerupuk karak dengan ekstark rumput laut $100 \mathrm{ml} / 1 \mathrm{~kg}$ nasi dilakukan uji gizi di laboratorium biotek jurusan Teknologi Hasil Pertanian Fak Teknologi Pertanian UGM untuk mengetahui kandungan gizinya. Berikut hasil uji gizi kerupuk karak dengan ekstark rumput laut $100 \mathrm{ml} / 1 \mathrm{~kg}$ nasi dengan dua kali ulangan:

Tabel 6 Hasil Uji Gizi

\begin{tabular}{|c|c|c|c|}
\hline sampel & Analisa & Ulangan I & Ulangan II \\
\hline \multirow{12}{*}{$\begin{array}{l}\text { Kerupuk } \\
\text { Karak }\end{array}$} & Air & 11,258 & 11,465 \\
\hline & Abu & 2,720 & 2,697 \\
\hline & Lemak & 3,395 & 3,734 \\
\hline & Protein fk;6,25 & 8,552 & 8,521 \\
\hline & Serat kasar & 2,995 & 3,009 \\
\hline & Karbohidrat by Diff & 74,075 & 73,583 \\
\hline & Kalori (kal/ 100gr) & 344,905 & 343,951 \\
\hline & Vitamin C (mg/ 100gr) & 7,902 & 7,899 \\
\hline & $\mathrm{Na}(\mathrm{ppm})$ & 10895,41 & 10920,08 \\
\hline & Fe (ppm) & 97,93 & 99,82 \\
\hline & $\mathrm{Mg}(\mathrm{ppm})$ & 240,56 & 241,78 \\
\hline & $\mathrm{Ca}(\mathrm{ppm})$ & 236,634 & 241,86 \\
\hline
\end{tabular}

Dari tabel diatas menunjukkan bahwa kerupuk karak dengan rumput laut mengandung gizi tinggi dengan rata-rata protein 8,5365; lemak 3,5645, karbohidrat 73,829, dengan kalori 344,428 kal/ $100 \mathrm{gr}$. Selain itu kerupuk karak dengan bahan pengental rumput laut mengandung vitamin $C 7,9 \mathrm{mg} / 100 \mathrm{gr}$; $\mathrm{Na}$ (ppm) 10907,75, Fe (ppm) 98,875, mg (ppm) 241,17; Ca (ppm) 239,247.

Melihat kandungannya maka kerupuk karak ini mengandung mineralmineral yang dibutuhkan manusia sehingga dapat disimpulkan bahwa kerupuk karak ini aman dikonsumsi. Karena lemaknya yang kecil sehingga karak ini aman bagi penderita kolesterol. Dengan kadar Ca tinggi baik untuk dikonsumsi anak-anak dalam pembentukan tulang, dan bagi dewasa dapat mengurangi 
kebutuhan Ca dalam menekan oestophorosis. Disamping itu juga mengandung Vitamin $\mathrm{C}$ guna kekebalan tubuh.

h. Kelebihan kerupuk karak dengan rumput laut

1. Dari fisik kerupuk karak dengan rumput laut lebih menarik daripada kerupuk karak menggunakan bleng.

2. Dari rasa kerupuk karak dengan rumput laut lebih enak dibanding kerupuk karak menggunakan bleng, juga tidak menimbulkan rasa getar.

3. Dari segi gizi, kandungan mineral rumput laut dibutuhkan oleh tubuh yang meningkatkan kesehatan. Kerupuk karak dengan rumput laut dengan kadar lemak kecil aman dikonsumsi bagi penderita kolesterol, dengan kandungan vit $\mathrm{C}$ tinggi dapat meningkatkan kekebalan tubuh, dengan kandungan $\mathrm{Ca}$ maka dapat dikonsumsi bagi anak-anak dalam pembentukan tulang dan orang dewasa untuk menggurangi oestoforosis.

\section{KESIMPULAN}

Rumput laut memiliki kandungan alginat, karaginan, dan agar yang merupakan bahan pengental alami. Rumput laut jenis Eucheuma cottoni memiliki kadar karaginan tinggi (54-73\%) yang dapat digunakan sebagai bahan pengental. Dari hasil penelitian dapat menunjukkan bahwa rumput laut jenis Eucheuma cottoni dapat digunakan sebagai bahan pengental, dari uji organoleptik dan uji hedonik komposisi kerupuk karak dengan rasa, tekstur, dan warna yang paling baik adalah komposisi ekstrak rumput laut $100 \mathrm{ml} / 1 \mathrm{~kg}$ nasi. Dari analisa usaha kerupuk karak dengan menggunakan krumput laut layak dikembangkan dilihat dari analisa usaha dengan $\mathrm{R} / \mathrm{C} 1,45$. Dari hasil uji gizi kerupuk karak dengan bahan pengental rumput laut memiliki rata-rata protein 8,5365; lemak 3,5645, karbohidrat 73,829, dengan kalori 344,428 kal/ $100 \mathrm{gr}$. Selain itu kerupuk karak dengan bahan pengental rumput laut mengandung vitamin C 7,9 mg/ 100gr; $\mathrm{Na}$ (ppm) 10907,75, Fe (ppm) 98,875, mg (ppm) 241,17; Ca (ppm) 239,247.

\section{DAFTAR PUSTAKA}

Angka, SL, Maggy T dan Suhartono. 2000. Bioteknologi Hasil Laut. Pusat Kajian Sumberdaya Pesisir dan Lautan: Institut pertanian Bogor.

Anonim. Bahan Tambahan Pangan. Tersredia dalam [http://pharmacypoltekkestanka.blogspot.com, di download: 7 Maret 2013]

Atmadja, W.S., Kadi, A., Sulistijo \& Rachmaniar. 1996. Pengenalan jenisjenis rumput laut Indonesia. Jakarta: PUSLITBANG Oseanologi. LIPI.

Ceamsa. 2001. Gelation in carrageenan. www.ceamsa.com [7 Maret 2013].

Chapman VJ. 1970. Seaweed and Their Uses, Second Edition. London: Mathuen and Co. Ltd. 
Fardiaz D. 1989. Hidrokoloid. Bogor: Laboratorium Kimia dan Biokimia Pangan, Pusat Antar Universitas Pangan dan Gizi, Institut Pertanian Bogor. 